\title{
A "Liturgical Mysticism of Open Eyes": Johann Baptist Metz, Caryll Houselander, and Pandemic Liturgy
}

\author{
Samantha Slaubaugh
}

Citation: Slaubaugh, Samantha. 2021. A “Liturgical Mysticism of Open Eyes": Johann Baptist Metz, Caryll Houselander, and Pandemic Liturgy. Religions 12: 685. https:// doi.org/10.3390/rel12090685

Academic Editor: Edward Foley

Received: 15 July 2021

Accepted: 23 August 2021

Published: 26 August 2021

Publisher's Note: MDPI stays neutral with regard to jurisdictional claims in published maps and institutional affiliations.

Copyright: (C) 2021 by the author. Licensee MDPI, Basel, Switzerland. This article is an open access article distributed under the terms and conditions of the Creative Commons Attribution (CC BY) license (https:/ / creativecommons.org/licenses/by/ $4.0 /)$.
Department of Theology, University of Notre Dame, Notre Dame, IN 46556, USA; sslaubau@nd.edu

\begin{abstract}
The German theologian Johann Baptist Metz (1928-2019) called for a spirituality that sees more suffering, not less, the more liberated it is; he has described this as a "mysticism of open eyes." This theological vision involves all people, living and dead, becoming free to stand as subjects before God. Caryll Houselander (1901-1954), an English author, developed a liturgically infused mysticism focused on seeing Christ in each person. Her vision of Christ in others was rooted in creatively portraying the particularities of human life in the great "rhythm" of the Christ-life lived in the Mystical Body and expressed in the liturgy. This article proposes that juxtaposing these two authors reveals a "liturgical mysticism of open eyes," playing off Metz's initial phrasing. The work of Metz and Houselander together presents a fruitful liturgical theology for Christian communities during and in response to the pandemic as they engage questions of suffering, justice, and responsibility. By rooting our decisions about liturgical and social lives in a "liturgical mysticism of open eyes," the church may remain rooted to a liturgical spirituality, while also recognizing and being open to the suffering of individuals and communities while liturgies are altered, moved online, or postponed altogether.
\end{abstract}

Keywords: Johann Baptist Metz; Caryll Houselander; COVID-19; pandemic; social justice; suffering; oppression; liturgy; worship; ethics

\section{Introduction}

At first glance, there seems to be little in common between Johann Baptist Metz (1928-2019), the German priest and professional theologian known for political theology, and Caryll Houselander (1901-1954), the English lay theologian and artist known for liturgically infused work. However, each theologian was deeply marked by World War II, making a theology of the passion, or of compassion, a primary aspect of their work. Their experiences of mass death and suffering make both Metz and Houselander helpful sources of theology as the world reels from the loss of life and suffering caused by both the coronavirus pandemic and the oppression that flows from white supremacy and Western colonialism. ${ }^{1}$ Reading the two together, moreover, further enriches the gaps in each author's thought. While Metz worked on political theology, he did not develop a liturgical and sacramental focus. Scholars such as (Morrill 2000) and (Eggemeier 2012) have taken up this lacuna in Metz, proposing other authors to complement Metz. Houselander, on the other hand, focused greatly on liturgy and sacramental life while saying much less on political theology. However, each author presents, through different approaches, a mystical theology of openness to the other in which the memory of Christ is brought to bear as an interpretive framework for both the present and the future. Metz's "mysticism of open eyes" combines with Houselander's liturgical mysticism into a "liturgical mysticism of open eyes," that challenges us today to make choices for our communities of faith through a rootedness in liturgy that does not distort the memory of Christ's passion. To support this claim, this essay first examines Metz's theological vision of a mysticism of open eyes. Second, it looks at key themes in Houselander's liturgically rooted mystical theology. Finally, the essay concludes with questions aimed to interrupt our practice of liturgy in light of both the 
coronavirus pandemic and concerns for social justice. These interrupting questions invite us to consider how a solidaristic liturgy looks in our particular communities as we wrestle with racism, death, and physical and emotional suffering in a pandemic.

\section{Johann Baptist Metz: "Mysticism of Open Eyes"}

To begin a fruitful juxtaposition of Metz and Houselander, one should start first with an exploration of what Metz envisioned in the phrase "mysticism of open eyes." Metz argued that "Jesus did not teach an ascending mysticism of closed eyes, but rather a God-mysticism with an increased readiness for perceiving, a mysticism of open eyes, which sees more and not less. It is a mysticism that especially makes visible all invisible and inconvenient suffering, and-convenient or not-pays attention to it and takes responsibility for it, for the sake of a God who is a friend to human beings" (Metz 1998, p. 163). For Metz, a true mysticism, one in which a person enters the mystery of their own existence as a subject in God's presence, is always a mysticism that sees more of life and not less. Metz was not interested in a mystical "opium" in which those uncomfortable with the pain and suffering of the world escape to an ethereal experience of oblivion before God. Rather, to be a subject before God is to be a "witness," one who is "involved, with eyes that see, in that history where people are crucified and tortured, hated and miserly loved;" for as Metz argues, only in "how we deal with others ... can it be known how we think about God and what we think of God" (Metz 1998, p. 163). Simply put, a "mysticism of open eyes" is "a mysticism of an unconditional obligation to feel the suffering of others" (Metz 2005, p. 32).

Metz's approach to articulating a Christian mysticism reaches to the core of his own practical fundamental theology. For Metz, theology is "mystical-political" (Metz 2007, p. 29); that is, theology is never merely pure doctrine dressed up later in praxis and narrative. Theology is always both practical and fundamental. Praxis and doctrine are intertwined and misunderstood when separated from each other. Metz articulated this succinctly when he argued that "Christ must always be thought in such a way that he is not just thought. ... every Christology is nourished by a praxis: the praxis of discipleship" (Metz 2007, p. 62). This discipleship must be understood as a praxis of suffering since it cannot be achieved apart from Christ's own command to "pick up your cross and follow me."

Praxis as suffering is not masochistic but liberating; "the history of suffering [is] a history of freedom" (Morrill 2000, p. 31). The willingness to see more suffering and to have a mysticism of open eyes is a type of resistance to apathy. This praxis extends from a Christology that flows first and foremost from the cross; therefore, a mysticism of open eyes is a mysticism that sees the doctrine of Christology flowing from the "dangerous" memory of Christ's passion, death, and resurrection. Metz explained that this memory "holds a particular anticipation of the future as a future for the hopeless, the shattered and oppressed. In this way it is a dangerous and liberating memory, which badgers the present and calls it into question" (Metz 2007, p. 89). As dangerous as this memory is-for it takes one away from the safe, distant God who has little practical impact-it is fundamentally a liberative memory. The ability to remember this dangerous narrative of God coming into the world, suffering, and rising again frees one to see with open eyes the very narrative itself in one's own particular social and historical context. Metz's own thought is characterized by the need to take his own witness of suffering "not to the psychologist but into the church" (Metz 1998, p. 2). During World War II, upon returning from delivering a message, Metz found his whole company dead; he began to ask, "what would happen if ... one did not allow oneself to be talked out of such unreconciled memories even by theology, but rather wanted to have faith with them and, with them, speak about God?" (Metz 1998, p. 2). As the death of others was a foundational event for Metz's theological thought, he understands a mysticism of suffering to be rooted not in "a self-referential memory of suffering (the root of all conflicts!), but in the form of a memory of others' suffering, in the form of a remembrance of the stranger's suffering" (Metz 2005, p. 33).

In addition to the memory of suffering, the memory of Christ's passion, death, and resurrection, Metz also focused on two other concepts that illuminate a mysticism of open 
eyes, namely, narrative and solidarity. ${ }^{2}$ As for narrative, Metz claimed that " $[\mathrm{t}]$ he logos of the cross and of the resurrection has an indispensable narrative structure. Confronted with the human history of suffering, faith ... is passed on in dangerous-liberating stories, under the impact of which those hearers who are affected by them become 'doers of the word" (Metz 2007, p. 194). By narrating one's own world into the narrative of the dangerous memory of Christ's passion, death, and resurrection, the creedal and doctrinal content of faith becomes "understood as formulas in which this challenging remembrance is spelled out publicly" (Metz 2007, p. 89). Proclaiming the dangerous memory of Christ in history requires liberated mystical sight, as this sight is the way to true solidarity with all people, and thus the way for every person to become free to be subjects. This is the "task given to religion," according to Metz, namely, "to stand up so that all persons might be subjects in solidarity, just as much when confronted by violent oppression as in the face of the caricature of solidarity found in formed massification and in institutionalized hatred" (Metz 2007, p. 59). ${ }^{3}$ Metz holds in tension a critique of privatization that results from the Enlightenment and the opposite extreme of "massification," or the "abstract negation of the individual" (Metz 2007, p. 59). To be a subject before God is to stand before God fully as oneself, related always and already to all other subjects. The individual is always unique, but always also realized in communion. The paradox of particularity and universality is a constant thread woven throughout Metz's vision of a "mysticism of open eyes" which sees the universality of the dangerous memory of Christ always in its particular iterations in history. ${ }^{4}$

Every historical and social context must be viewed through and integrated into this narrative of the dangerous memory. As such, a mysticism of open eyes is a mysticism of interruption. The suffering of others, convenient or not, interrupts our understanding of the narrative and asks pointed questions about one's own and one's community's responsibility and response to the memory of the passion, death, and resurrection that is being lived out in a given time and place. This mysticism of open eyes is intertwined with the praxis of discipleship, what Metz called a "practical Christ-formedness" which is the sign of the Spirit at work (Metz 2007, p. 155). Although brief, this summary of Metz's mysticism of open eyes should be enough to offer a comparison with Houselander's own theology. However, two final points are important to highlight.

First, the solidarity implicated in a mysticism of open eyes extends even to the dead who have been vanquished and forgotten. Metz argued that solidarity is "expanded into an anamnestic solidarity, a solidarity of memory with the victims of history" (Metz 2007, p. 68). The dead victims of history are exemplary of the type of solidarity Metz proposed is required by a mysticism of open eyes; "when it comes to the dead there is no exchange relationship ... The love that mourns for the dead is that form of love ... that cannot be taken up into a consumer society's exploitation structures" (Metz 2007, p. 51). The dead have nothing to offer the living from a consumer standpoint. Yet, the eschatological content of the memory of Christ's passion, death, and resurrection makes space in particular for the dead, who are promised resurrection. Therefore, a mysticism of open eyes sees not only the living who suffer, but also the dead who have suffered and been forgotten. This solidarity interrupts and shapes an eschatological understanding of the hoped-for future.

Second, the praxis of solidarity is well-expressed in prayer, in which one is free to stand as a subject before God in solidarity with all people, not as a privatized individual. While Metz did not expound in depth on liturgy, ritual, and sacrament-what Matthew Eggemeier calls "distinctive lacunae" (Eggemeier 2012, p. 54)—his own theological project dovetails naturally with liturgical theology. Bruce Morrill has demonstrated this point by placing Metz and Alexander Schmemenn in conversation (Morrill 2000). Moreover, prayer, ritual, and sacrament are not in contradiction to Metz's theological vision, though they are subject to manipulation by bourgeois religion. Metz was concerned with liturgy that enables a spirituality of closed eyes. He argued that a liberated spirituality "cannot be limited to a purely cultic experience, isolated from and unburdened by conflicts, repression, and challenges in everyday life" (Metz 2007, p. 93). In contrast with a "purely cultic" spirituality, 
Metz envisioned a church that "has an ear for the dark prophecy of this suffering of others" (Metz 2007, p. 94). Moreover, Metz did call for the integration of "the sacramental event into stories of life and of suffering ... [to] make it clear that the sacramental event is a narrative of salvation within these stories" (Metz 2007, p. 190). Not only is liturgy relevant to Metz's work due to its narrative structure of proclaiming the dangerous memory of Christ, but in prayer God "calls us to become subjects or unconditionally support others becoming subjects ... and [God] calls us to remain subjects in the face of guilt and in opposition both to the dissolution of individual identity into 'the masses' and also to apathy" (Metz 2007, p. 80). Prayer is the place in which we narrate the memory of Christ in solidarity with all; that is true even especially if we bear guilt or responsibility for the oppression that takes away another's freedom to be subjects before God. Liturgy is where the history of the vanquished, not the conquerors, and the guilt and responsibility of the church must be proclaimed as interruptions to our liturgical theology and praxis, or else we will not be free to stand as subjects in solidarity before God.

\section{Caryll Houselander: Liturgical Mysticism}

Turning now to Caryll Houselander's articulation of mysticism, solidarity, and liturgy, both similarities and differences between her and Metz will become apparent. Houselander's mystical theology is captured by her description of three visionary experiences detailed in her autobiography, A Rocking-Horse Catholic. In the first vision at the beginning of World War I, she saw an ostracized Bavarian nun crying; Houselander looked down in embarrassment and when she looked back up, she saw the nun wearing the crown of thorns (Houselander 1988, p. 74). The nun whose nationality made her an enemy during the war was revealed as one participating in the passion of Christ. During the second vision in 1918, she saw an icon of Christ the King crucified floating in the sky; she later discovered that the vision of Christ had the face of the executed Russian Tsar, Nicholas II (Houselander 1988, p. 111). Houselander explained how this vision taught her that Christ's life was even lived by the wealthy and powerful. The third vision occurred when Houselander boarded a full underground train. She described how "quite suddenly I saw with my mind ... . Christ in them all. ... not only was Christ in every one of them, living in them, dying in them, rejoicing in them, sorrowing in them-but because He was in them, and because they were here, the whole world was here too.... not only all the people in all the countries of the world, but all those people who had lived in the past, and all those yet to come" (Houselander 1988, pp. 137-38). Houselander highlighted the theological broadening of these visions, stating that her third vision "was not a seeing of Christ in one person, as it had been with the Bavarian nun, or in one particular sort of person, as it had been in the living icon of Christ the King. This time it was Christ in all" (Houselander 1988, p. 137). Finding Christ in all people and situations was the core of Houselander's theological project.

After her mystical experience, she captured this mysticism of open eyes in her theological and creative work. While Metz's articulation of the mysticism of open eyes is best understood through the categories of memory, narrative, and solidarity, Houselander's used the themes of creativity, rhythm, and the Christ-life. First, moving beyond narrative, Houselander affirmed all creative work is integral to the structure of theology. In The Risen Christ, she described Christ as the archetypal artist who creates out of overflowing love in the Trinity; therefore, "we can all be artists and creators: in our attitude to our work we can make what we make first of all for love" (Houselander 1958, p. 84). Second, integral to the ideal of creativity is Houselander's concept of "rhythm." She did not describe her poetry as poems but as "rhythms." She wrote to a friend that "I have for a long time felt that a kind of communion of contemplation among us all is what is needed in the world, and I deliberately write Rhythms and give them to all sorts of people in order to start some recollection in their souls" (Houselander 1945, "From a Letter to Maisie Ward"). Rather than letting prayer take her out of the world, the Rhythms were a way in which Houselander brought the world into her prayer. Similar to Metz, she envisioned a spirituality that was not an 
ascending escape from suffering, but one in which God descends to the world, present even in its mundane experiences as a Rhythm that beats from the life, passion, death, and resurrection of Christ.

Third, Houselander argued that human life partakes in the one life of Christ, the artist whose rhythm of love unites all creation. In This War is the Passion, written about World War II, she claimed that "because [Christ] has made us 'other Christs,' because his life continues in each one of us, there is nothing that any one of us can suffer which is not the passion he suffered. Our redemption, although it was achieved completely by our Lord, does, by a special loving mercy of his, go on in us. It is one unbroken act which goes on in the mystical body of Christ on earth, which we are" (Houselander 2008, p. 1). The Christ-life is not so much an imitatio Christi that is accomplished by one's own effort, but rather, as in Houselander's third mystical vision, it is Christ himself living mystically in each individual. What is required, according to Houselander, is simply to learn to recognize the Christ-life being lived not only in one's own life, but in the life of each person. In other words, we must have open eyes to the suffering of Christ lived in the world. Similar to Metz, Houselander did not see Christ's universal presence in humanity as leading toward some unnamed mass of people that we are called to think about. Rather, both authors are clear that the universal and the particular are met in Christ, neither confused nor divided. Christ is in all but uniquely in each.

Parallel to the two notes on Metz's work, I wish to highlight two aspects of Houselander's thought. First, while Metz privileged the dead, Houselander privileged children and infants, another category of humanity that are often forgotten as real subjects. A survey of Houselander's work reveals that while she spent a great deal of time on the passion of Christ, the life of the Christ-child, both in actual children and in adults, is a primary theme. The two are not separate moments as much as they are the beginning and end of a circle; as Houselander put it, "Bethlehem is the inscape of Calvary" (Houselander [1949] 1995, p. 69). Houselander taught that all are to become as little children by living the Christ-child life, by which she envisioned, "we must get back true values instead of those that are based on materialism, public opinion, and snobbery; ... we must regain simplicity and humility ... we must become makers and poets again" (Houselander [1949] 1995, p. 87). Houselander emphasized that being subjects before God requires us to become as the Christ-child, which is deeply related not only to creativity but also to a praxis of suffering. "If the infant Christ is fostered in us, no life is trivial. No life is impotent before suffering, no suffering is too trifling to heal the world, too little to redeem, to be the point at which the world's healing begins" (Houselander [1949] 1995, p. 101). Houselander's focus on children is best understood as a way to see Christ in the suffering of those who have the least to contribute to society and are thus ignored or forgotten.

Second, unlike Metz, Houselander's mysticism is explicitly related to the liturgical and sacramental life of the church. Houselander taught that "the Liturgy is the expression of Christ's love, his prayer in his Mystical Body, into which our own prayer is gathered and integrated" (Houselander 1958, p. 68). Liturgy is also "the supreme expression on earth of the rhythmic Law of God" (Houselander [1949] 1995, p. 43). Unlike Metz, who mostly gestures provocatively toward the necessity of expounding upon the narrative structure in the liturgical and sacramental life of the church, Houselander actively narrated both the life of the world into the liturgy and the liturgy into the life of the world. "Houselander describes everyday occurrences in her life using the vocabulary of the liturgical rites of the church" (Petrin 2020, p. 224). In a rhythm titled "Low Mass on Sunday," Houselander affirmed a mysticism of open eyes that is rooted in the communion of the faithful:

They are not more blessed

whose feet

are set on the mountain path,

who abide in the cloud,

content with the touch 
of a God who is featureless,

than we

who, weaker in faith,

learn by touching His wounds

in the human race

that our hands

touch with His power to heal:

than we, at the wedding

of earth and Heaven,

turning the water to wine

by a fling of the heart

to God-

in the lowliest,

in the nearest at hand.

We are the simple bread

ground for the simpler Host.

(Houselander 1945, p. 36)

Christ is not present in the host as if it were the hidden, featureless face of Christ in a cloud of darkness. Rather, the communion at mass is the communion of the people; they are the grain ground, baked, and broken together into the host, into Christ. "It is the breaking of the Bread which is the Communion of all [humans] in Christ, in which the multiple lives of the world are one Christ-life, the fragmentary sorrows of the world are one Christ-Passion" (Houselander [1949] 1995, p. 148). For Houselander, the liturgy was foundational for living a life with eyes open to see Christ in others. In this sense, I follow Eggemeier's lead in drawing upon other authors to illuminate what embodied practices form individuals, and in this case, entire communities, to not only see but also respond to the suffering of the world. Eggemeier discusses Sarah Coakley and Simone Weil as authors who argue for the role of contemplative prayer as a tool for responding to suffering; contemplation trains us to pay attention (Eggemeier 2012, pp. 54-57). In a similar vein, Houselander's work points to embodied practices missing in Metz's articulation of a "mysticism of open eyes." The liturgy opens our eyes, trains us to pay attention, and invites our bodies to participate in that dangerous memory of the passion, death, and resurrection of Christ. To read Metz and Houselander together, then, is to find a "liturgical mysticism of open eyes".

\section{Conclusions: Questions for Liturgical Theology and Praxis in Light of the Pandemic}

Turning then to our current situation, what might reading Metz and Houselander together contribute to our liturgical theology and praxis during a time when inequality in our society has been highlighted in so many ways? According to Metz, a mysticism of open eyes is a liberation that allows one to stand in true solidarity with others by means of the narrative of the dangerous memory of the passion, death, and resurrection of Jesus. According to Houselander, a liturgical mysticism is to see and then creatively proclaim the life, passion, death, and resurrection of Christ as told by the liturgy in the lives of every individual. Combining Metz's political theology with Houselander's liturgical theology leads to a "liturgical mysticism of open eyes." The liturgy is the place in which we publicly remember the dangerous memory of Christ's passion, death, and resurrection in order to have our eyes opened by God's grace to see the Christ-life in others. The implications of grounding our faith communities in a liturgical mysticism of open eyes are going to differ depending on the ecclesial and local community and thus cannot be fleshed out here with any completeness. Instead, I wish to ask a handful of questions that might helpfully 
interrupt our liturgical theology and begin to explore how answers to these questions might empower our liturgical praxis to publicly proclaim the dangerous memory of the Christ-life being lived in and around us.

First, are the most forgotten persons and those suffering the most in society the ones at the core of our theological understanding of Christ in the liturgy? If we follow Metz and Houselander, decisions about safety precautions in a pandemic must be made with a primary focus on the impact of these decisions for those whom society pushes to the margins and those who have been deprived of the power to prevent their own suffering from disease or injustice. It has become evident that those generally marginalized by systems of oppression are those who are suffering at a higher rate and with greater consequence from COVID-19. ${ }^{5}$ The making and enforcement of safety decisions, such as masking, social distancing, or outdoor and online worship, must be made for the sake of those neglected by society, whether they be in the pews or not. Furthermore, these decisions must be communicated in such a way that it invites and empowers congregants to see the suffering caused by the pandemic as a narrative of Christ's passion and death. Our catechesis on these decisions should open eyes to see the mystical presence of Christ in those who suffer behind hospital curtains, nursing home doors, factory walls, and redlined neighborhoods. In practice, this might mean holding pastoral listening sessions with congregants who are upset about safety precautions put in place; it might result in tailoring sermons to such catechetical purposes; it might entail virtual communications that mystagogically interpret new liturgical symbols such as the space between congregants, the computer screen, masks, spiritual communion, and a lack of singing. ${ }^{6}$

Additionally, with an understanding that those who suffer injustice and oppression are at the heart of the liturgy and that they have a unique authority to witness to the memory of the passion, death, and resurrection of Christ, ministry teams and parishioners alike ought to actively listen to the voices of those risking their lives to, suffering, and dying from COVID-19, racism, and all forms of disasters and systemic oppression. Churches ought to be consistently centering these marginalized and suffering voices with the understanding that the proclamation of the gospel cannot stand apart from their witness and active contribution. Thus, churches should also examine their visible liturgies. Who do people see in the pews? Who do they see in leadership? Who do they see in the artwork that adorns the space, be it virtual or physical? Who are we missing at our eucharistic table, in our ordained and lay leadership, and in our proclamation of the gospel? Is the liturgical setting excluding those on the margins or is it re-centered around them? A liturgical mysticism of open eyes should flow from and lead to a visible performance of the liturgy that symbolizes its eschatological hope of liberation and redemption through art, lay and clerical performance, and text.

Second, are we turning to liturgies to creatively protest injustice and memorialize the dead? Houselander especially challenges our churches to embrace the creative aspect of liturgy flowing from God the Artist. Therefore, making changes due to safety precautions should be viewed as an opportunity to perform and creatively narrate the memory of the passion, death, and resurrection of Christ in a pandemic. If liturgy is a public proclamation of this dangerous memory, can more outdoor liturgies and public services that are not eucharistic (therefore avoiding exclusion around the Eucharist) aid in this proclamation? Gathering safely outdoors would be a public performance of the church's active response to the witness of suffering in the pandemic. Moreover, churches should be striving to draw from the liturgical riches of tradition in meeting the crisis of death and suffering caused by the pandemic and oppression of all kinds. Churches have long held a unique societal role in remembering and praying for the dead. Congregations can turn to their tradition's liturgical repertoire, adapting these liturgies when necessary, and perform liturgies in memory of all who have died during this pandemic. Whether this be requiem masses, the office of the dead, or memorial services, celebrating these liturgies as the church could act both as a liturgical reminder to parishioners to see the dead and the suffering and also as a public service for the mourning community. Additionally, with a vast history 
of processional liturgies and call-and-response litanies, Christian churches have the tools to mystagogically interpret protests for justice as a liturgical act. Moreover, the church can actively utilize outdoor processions to safely perform memorials for the dead and petitions for those suffering injustice, perhaps processing to local memorial sites, around hospitals, places of racial violence, or prominent public places. The physical movement of diverse bodies coming together and marching forward has potential to be both therapeutic in healing divisions and also prophetic in their public petitions to God for injustices to be made right.

Third, and finally, do we encourage worshipping communities to stand as subjects before God by not rejecting our guilt and the responsibility that follows true solidarity? Both public health measures and efforts for racial justice have encountered pushback inside the church. However, confession is an integral part of nearly every liturgy, not to mention a sacrament in several denominations. Christians then, should be equipped through their liturgical formation to clearly and humbly acknowledge their sins, both communal and personal. Our liturgies might better reflect this need to accept the guilt and responsibility that flows from solidarity with the suffering by adding or editing an invitation to confession that addresses the church's role in profiting from or causing oppression and suffering in the world, including through racism, colonialism, climate change, abuses of power, etc. ${ }^{7}$ Our petitions can also reflect an outward concern for justice and an inward desire for our own communal turning from sin and to God. The sending out at the end of many liturgies too, might better reflect our current situation and be a specific call to fight for justice in our communities given our own eucharistic liberation from sin. The rhythm of the Christian liturgy from confession to communion to mission into the world invites the church to stand in solidarity, unafraid of their own guilt. God's mercy meets us, redeems us, and sends us into the world to perform communal penance as we fight for justice and take responsibility for injustices. Beyond eucharistic liturgies, could public liturgies of repentance for the church's own complicity in systems of oppression be formative for congregants and offer those harmed by the church a step toward full justice?

If we listen to Metz and Houselander, our liturgical theology and praxis will flow from our answers to these questions, and our answers must be formed by centering and listening to those who are suffering most in this pandemic. When this work begins, our liturgies will strive to reject a false peace without justice; they will turn from a privatized cultic experience where individuals are severed from a communion of solidarity. In the face of suffering and inequality, the liturgy should challenge us to open our eyes to the dangerous memory of the passion, death, and resurrection in the vanquished, forgotten, and oppressed; it should be where we creatively work in solidarity to shape our hope for the future in light of the Christ-life being revealed in the present.

Funding: This research received no external funding.

Conflicts of Interest: The author declares no conflict of interest.

\section{Notes}

$1 \quad$ For an English introduction to the work of Metz, see (Ashley 1998). The scholarship on Metz is significant; Houselander is much less studied. Ward (1962) is a well-known biography, and there are several academic articles looking at Houselander's writings such as Coulter (1990), Meconi (2014), Meszaros (2015), and Petrin (2020).

2 These are not the only two themes relevant to a full understanding of Metz's work, of course. For an overview of Metz's six "central elements" in Faith in History and Society, see (Morrill 2000, pp. 21-26).

3 See (Vento 2002) for an analysis of how Metz's focus on suffering can contribute to feminist theology in light of violence against women and the resulting necessary political resistance.

4 For example, in the "biographical itinerary" that precedes A Passion for God, Metz explains: "I have worked to formulate a concept of theology that, while it recognizes the post-modernists' legitimate suspicion of universalistic approaches, does not collapse into a sheer relativization of cultural worlds. I have striven to do this by stressing a respect for and obedience to the authority of those who suffer. For me this authority is the only one in which the authority of the sovereign God is manifested in the world for all men and women" (Metz 1998, p. 4). 
The Centers for Disease Control and Prevention, for example, indicate that "Race and ethnicity are risk markers for other underlying conditions that affect health, including socioeconomic status, access to health care, and exposure to the virus related to occupation" (CDC 2021).

6 Houselander herself engaged in this catechesis in This War is the Passion, giving a step-by-step method for spiritually praying the mass should it not be available during the bombings of London. Her catechesis focuses on lay participation, stating that the mass "is not a sacrifice offered by a priest in which our part is merely that of a devout audience. It is a sacrifice which gathers every circumstance of our life to itself and is the very core of our being" (Houselander 2008, p. 90).

7 See (Ramshaw 2017) for examples of laments on "Disease and Infirmity" (p. 22), "Injustices in Society" (p. 23), and "Damage to the Earth" (p. 24).

\section{References}

Ashley, James Matthew. 1998. Interruptions: Mysticism, Politics, and Theology in the Work of Johann Baptist Metz. Notre Dame: University of Notre Dame Press.

CDC—Center for Disease Control and Prevention. 2021. Risk for COVID-19 Infection, Hospitalization, and Death by Race/Ethnicity. Available online: https:/ / www.cdc.gov/coronavirus/2019-ncov/covid-data/investigations-discovery/hospitalization-deathby-race-ethnicity.html (accessed on 14 July 2012).

Coulter, Moureen. 1990. 'A Mirror Set before the Face of God,' Art and Mysticism in the Work of Caryll Houselander. Studia Mystica 13: 83-95.

Eggemeier, Matthew T. 2012. A Mysticism of Open Eyes: Compassion For A Suffering World And The Askesis Of Contemplative Prayer. Spiritus: A Journal of Christian Spirituality 12: 43-62. [CrossRef]

Houselander, Caryll. 1945. The Flowering Tree. New York: Sheed and Ward.

Houselander, Caryll. 1958. The Risen Christ. New York: Sheed and Ward.

Houselander, Caryll. 1988. A Rocking Horse Catholic. Westminster: Christian Classics, Inc.

Houselander, Caryll. 1995. Wood of the Cradle, Wood of the Cross. The Little Way of the Infant Jesus. Manchester: Sophia Institute Press. First published 1949. The Passion of the Infant Christ. New York: Sheed and Ward.

Houselander, Caryll. 2008. This War is the Passion. Notre Dame: Christian Classics.

Meconi, David Vincent. 2014. Two Apostles of Loneliness: Caryll Houselander and Catherine Doherty on the Mystical Body of Christ. Logos: A Journal of Catholic Thought and Culture 17: 58-76. [CrossRef]

Meszaros, Julia. 2015. The Doctrine of 'Divine Indwelling' in Elizabeth of the Trinity and Caryll Houselander. New Blackfriars 96: 465-80. [CrossRef]

Metz, Johann Baptist. 1998. A Passion for God: The Mystical-Political Dimension of Christianity. Translated by J. Matthew Ashley. Mahwah: Paulist Press.

Metz, Johann Baptist. 2005. God: Against the Myth of the Eternity of Time. In The End of Time? The Provocation of Talking about God. Translated by J. Matthew Ashley. Mahwah: Paulist Press.

Metz, Johann Baptist. 2007. Faith in History and Society: Toward a Practical Fundamental Theology. Translated by J. Matthew Ashley. New York: The Crossroad Publishing Company.

Morrill, Bruce. 2000. Anamnesis as Dangerous Memory: Political and Liturgical Theology in Dialogue. Collegeville: The Liturgical Press.

Petrin, Anna Adams. 2020. Insights from Mrs. Murphy: Caryll Houselander as Liturgical Theologian. Worship 94: $206-27$.

Ramshaw, Gail. 2017. Pray, Praise, and Give Thanks: Litanies, Laments, and Thanksgivings at Font and Table. Minneapolis: Augsburg Fortress.

Vento, Johann M. 2002. Violence, Trauma, and Resistance: A Feminist Appraisal of Metz's Mysticism of Suffering unto God. Horizons 29: 7-22. [CrossRef]

Ward, Maisie. 1962. Caryll Houselander. That Divine Eccentric. New York: Sheed and Ward. 